\title{
EU Citizenship Should Speak Both to the Mobile and the Non-Mobile European
}

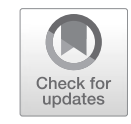

\author{
Frank Vandenbroucke
}

\begin{abstract}
Maurizio Ferrera tables a catalogue of proposals to add a social dimension and 'some duty' to EU citizenship. As always, his search for incremental solutions that reconcile feasibility and vision is challenging. However, I have some sympathy with Joppke's reaction that one cannot dispense with a more fundamental debate on free movement, on which public opinion is deeply divided. Ferrera's proposals may be relatively peripheral to settling that fundamental debate. On the other hand, Joppke's insistence that EU citizenship is duty-free, because it is liberal, does not yield a justification for free movement and non-discrimination of mobile Europeans. I believe it is possible to justify free movement in a framework of principles that speak both to the mobile and the non-mobile European, whereby openness is embedded in principles of reciprocity. Reciprocity bridges rights and obligations.
\end{abstract}

To clarify the issues at hand, we should distinguish three questions:

1. How can we justify free movement?

2. How can we justify non-discriminatory access to social benefits for those who move?

3. How can we justify a difference between active and non-active citizens in the application of (1) and (2)?

\section{Why free movement for active citizens?}

Simply postulating that EU citizenship implies free movement begs the question. The most robust normative justification holds that free movement of workers means that EU citizens share an opportunity set, which is much larger than the opportunity sets offered by separate national labour markets. If free movement is about 'equal access to opportunities' across borders for all Europeans, it is hard to see how it can be mitigated or nuanced on a permanent basis (which is different from postponing it during a transitory period): either equal access applies for everybody - for the low-skilled as 
much as for the high-skilled, for all kinds of jobs -, or it does not apply, at least as long as equal access to opportunities is so conceived. ${ }^{1}$

This normative justification is not premised on the idea that free movement would per se improve the position of the worst-off within the EU. The status of such a principle in a conception of social justice is comparable to Rawls' principle of 'fair equality of opportunity', which has priority over his 'difference principle': for Rawls, 'fair equality of opportunity' (which is about access to positions and offices) has to be respected, even if it would limit the scope for redistribution. But is there an inevitable trade-off? With regard to the distributive consequences of free movement, I agree with Joppke that there is something problematic in Ferrera's proposal to set up a compensation mechanism for countries experiencing intra-EU immigration. Next to Joppke's observation that national governments are not incurring budgetary losses because of immigration and should be responsible for securing adequate provision of social services for their residents, the "negative externalities' mentioned by Ferrera may be more real for countries of mass emigration than for countries of immigration. Therefore, such a proposal risks to be highly divisive in today's Europe. The only way to tackle the distributive risks associated with mobility is to be more demanding visà-vis member states with regard to the quality of their welfare states, notably in the realm of labour market regulation and the provision of social services - more demanding than the EU is today. The regulation of minimum wages is a prime example. Different traditions exist with regard to the regulation of minimum wages: in some member states public authorities set minimum wage levels, in other member states this is the exclusive domain of social partners. But, however minimum wages are determined, a common European principle should be that all workers are covered by minimum wage regulation: decent minimum wages should apply universally in the EU's member states, without exceptions for certain sectors, or types of jobs, or types of workers. A related example is access to social protection: there should be no jobs that do not create access to social protection. In short, if we don't want immigration to boost a precarious, hyper-flexible segment of labour markets, there should be limits to precariousness and flexibility across the board. Or, think about access to social services, which can be

1 There is no denying that formal equality of opportunity does not guarantee real, substantive equality of opportunity. This distinction is emphasized, rightly, by Bruzelius, C., C. Reinprecht \& M. Seeleib-Kaiser (2017), 'Stratified Social Rights Limiting EU Citizenship', Journal of Common Market Studies 55 (6): 1239-1253 (although I am not convinced by the policy solutions they propose - but space forbids to pursue this here). 
under pressure in municipalities or regions with significant immigration: member states should guarantee sufficient provision of social services to safeguard universal access, for non-mobile citizens as much as for mobile citizens. The debate on the European Pillar of Social Rights can be the starting point to develop such common principles. Admittedly, developing and translating such principles into tangible realities is an uphill battle in today's Europe; but there is no alternative if free movement is to be reconciled with domestic social cohesion.

Next to the principled case based on a notion of equality of opportunity, there is a second, more contingent argument in support of free movement: a single market needs both a regime of free movement of workers and a regime of posting of workers (which supports the freedom of service delivery), and the two regimes need each other and should constitute a wellbalanced and sustainable whole. Posting ${ }^{2}$ has become a controversial issue in the EU: it is difficult to control and generates problems of social dumping in particular economic sectors. Therefore, reform is necessary. However, one cannot dispense of a posting regime: an integrated market for services requires that workers can be sent to other member states for short-term projects, without being employed and affiliated to the social security system of the receiving country. Simultaneously, a single market needs a regime of free movement of workers seeking regular employment contracts in other countries as a necessary corollary to a regime of posting. ${ }^{3}$ Limiting free movement of workers (with the principles of non-discrimination it implies) between a country A and a country B while allowing posting would be unfair from the point of view of workers living in A, since it would make it impossible to work in B on the basis of the full social and employment policy regime in that country. Moreover, such an imbalance would enhance a dynamic of social dumping in B: the alternative 'non-dumping' option,

2 A 'posted worker' is an employee who is sent by his employer to carry out a service in another EU member state on a temporary basis. Posted workers are different from EU mobile workers in that they remain in the host member state temporarily and do not integrate in its labour market, as they maintain an employment contract with an employer in their home ('sending') country. In contrast to posted workers, EU mobile citizens who work in another member state and have an employment contract with an employer in the latter member state are entitled to full equal treatment with nationals in access to employment, working conditions and all other social and tax conditions.

3 I develop this argument in a paper on basic income, reciprocity and free movement: Vandenbroucke, F. (2017), 'Basic income in the European Union: a conundrum rather than a solution', ACCESS EUROPE Research Paper No. 2017/02, available at SSRN: https://ssrn.com/abstract=3011847. 
which some workers from country A might prefer (compared to the 'posting' option), is simply unavailable in such a scenario. For it to be fair to workers, an integrated, single market for services needs both a well-delineated posting regime and free access of workers to regular employment contracts in other countries.

\section{Why non-discrimination?}

There should be no denying that the case for free movement for workers has often been made on mainly economic grounds (with a view to the efficient allocation of factors of production), and that the principle of nondiscrimination, notably with regard to social security entitlements, has often been defended as a corollary of free movement: non-discriminatory access to social security entitlements associated with employment obviously facilitates free movement. In the previous section, I tabled an argument for free movement based on access to opportunities, which does not refer to the traditional economic efficiency argument. In addition, we need independent arguments for non-discrimination that are not premised on the idea that free movement should be promoted per se.

The fact that a mobile worker is incorporated in the solidarity circle of the country where he or she works is most often defended as crucial to European citizenship. Without appeal to European citizenship, there is another argument, premised on the idea that the European Union should be union of welfare states. The fact that a Polish worker enjoys the same social rights as Belgian workers when working and living in Belgium justifies that his employment generates the same social security contributions and tax revenue for the Belgian government as the employment of a Belgian national in Belgium. In other words, non-discrimination in terms of social rights justifies and so sustains the principle that we do not tolerate competition between the Polish and the Belgian social and taxation system on Belgian territory: such competition is a recipe for social dumping. The nondiscrimination principle establishes a notion of reciprocity across EU member states, in the following sense: all member states guarantee that all economically active mobile citizens will have equal access to social policies in each of the member states; simultaneously, all member states understand that including economically active mobile citizens in the solidarity circle of their host country protects these solidarity circles against practices of social dumping within their own territory. 


\section{Earned social citizenship}

The coexistence of national welfare states and free movement in the EU is made possible by a principle of 'earned social citizenship'. Historically, the tension between free movement and the bounded welfare state was reconciled by granting the right to move only to the economically active (and their dependents) to the exclusion of the economically inactive and by establishing a coordination regime for social security systems to the exclusion of social assistance. This simple dichotomy was not tenable, but, when the right to free movement became open to economically non-active citizens, EU citizens were granted a right of residence throughout Europe 'as long as they do not become an unreasonable burden on the social assistance system of the host Member State'. The 2014 Dano-judgment by the Court stresses that member states have 'the possibility of refusing to grant social benefits to economically inactive Union citizens who exercise their right of free movement solely in order to obtain another Member State's social assistance'. ${ }^{4}$ Dion Kramer sketches the combination of continuity and change in the evolution of the EU's principle of 'earned social citizenship' and situates that evolution in a broader notion of 'neoliberal communitarianism', which 'combines a communitarian care of the national welfare state with a neo-liberal emphasis on the individual's responsibility to achieve membership of that welfare community'. He labels it 'neo-liberal' since 'it becomes the individual's own responsibility, expressed in the form of 'earning' citizenship, to convert to a bounded community of economic, cultural and social values' ${ }^{5}$ Kramer sees dangers in the current evolution, as an expanding notion of individual responsibility, not only with regard to economic contribution but also with regard to cultural traits such as language, risks to be pushed further and further within the confines of the national welfare state itself. However, taking on board these cautionary notes, there is also a more positive reading of the notion of 'earned social citizenship' for mobile Europeans, at least if the EU would oblige its member states to develop comprehensive and adequate systems of minimum income protection and if an increasingly restrictive interpretation of what 'earned social citizenship' means can be avoided. In this more positive reading, a carefully delineated possibility for member states to exclude non-nationals from domains of social policy in which principles of compassion rather than

Dano, C-333/13, EU: C: 2014:2358, para 78, emphasis added.

Kramer, D. (2016), 'Earning Social Citizenship in the European Union: Free Movement and Access to Social Assistance Benefits Reconstructed',

Cambridge Yearbook of European Legal Studies 18: 270-301. The first quote is on p. 277; the second quote is on p. 272. 
principles of responsibility dominate (such as social assistance) would be a corollary of a duty for each welfare state to protect its own citizens against vulnerability on the basis of compassion.

I would indeed argue that in a 'European Social Union' - a true union of welfare states - two complementary logics can apply legitimately with regard to social citizenship if they are applied conjointly:

1. Economically active citizens have the right to take up employment opportunities across borders, and on the basis of employment they - and those who depend on them - 'earn' non-discriminatory access to all social benefits in the member state where they work, including protection against the consequences of involuntary inactivity (unemployment, illness). National regulations that guarantee fairness in labour markets apply fully to them. This serves both a pan-European notion of equal access to employment opportunities and the purpose of social cohesion in each welfare state.

2. A non-active citizen who needs protection cannot simply rely on any member state of his (or her) choice: his nationality determines the member state, which is first and foremost responsible for his protection. Under carefully delineated conditions, another member state to which he has no bond of nationality is allowed to say that the non-active citizen's social protection would create an 'unreasonable burden' on its welfare state (these conditions must substantiate that, in the absence of a real link with the host member state, the right of free movement was exercised solely in order to benefit from the host state's social assistance). In contrast, it would be 'unreasonable' for any member state not to provide adequate social protection for its national citizens, whatever the causes of their vulnerability and dependence.

Obviously, setting the boundaries between these logics is a complex task and raises many questions. As Verschueren pointed out, there is both a broad and a narrow interpretation of the Dano judgment to which I referred earlier. ${ }^{6}$ What are the exact conditions under which the notion of 'unreasonable burden' can be applied, and what is the role played by criteria of 'integration in the host country' to show a 'real link' with that country? The reciprocity that a member state can demand from nationals of another EU member state must be judiciously defined. Also, next to principles that apply to labour markets and income protection, a space of European social citizenship needs

6 Verschueren, H. (2015), 'Preventing "Benefit Tourism" in the EU: A Narrow or Broad Interpretation of the Possibilities Offered by the ECJ in Dano?',

Common Market Law Review 52 (2): 363-390. 
specific principles in the domains of education and health care. In addition, and importantly, if these logics lead to a regime of 'enter at your own risk' (whereby residence of non-active non-nationals is de facto tolerated, without guarantee of protection), this may lead to precariousness and marginalisation of non-nationals. ${ }^{7}$

I am not implying that, today, the EU and its member states apply these complimentary logics carefully and consistently: both with regard to "fair mobility' and minimum income protection for the non-mobile citizens there is an agenda to be taken up (some of Ferrera's proposals fit well into an agenda of 'fair mobility'). However, these complexities, tensions and risks do not make these complementary logics illegitimate as a general framework for regulating social citizenship in the EU. If those principles were applied consistently, EU citizenship would speak both to the mobile and the non-mobile citizen: it would support mobility, but also impose on member states the adequate protection of and delivery of social services to the non-mobile.

Open Access This chapter is licensed under the terms of the Creative Commons Attribution 4.0 International License (http://creativecommons.org/licenses/by/4.0/), which permits use, sharing, adaptation, distribution and reproduction in any medium or format, as long as you give appropriate credit to the original author(s) and the source, provide a link to the Creative Commons license and indicate if changes were made.

The images or other third party material in this chapter are included in the chapter's Creative Commons license, unless indicated otherwise in a credit line to the material. If material is not included in the chapter's Creative Commons license and your intended use is not permitted by statutory regulation or exceeds the permitted use, you will need to obtain permission directly from the copyright holder.

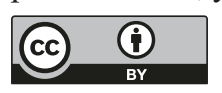

7 Heindlmaier, A. \& M. Blauberger (2017) 'Enter at your own risk: free movement of EU citizens in practice', West European Politics 40 (6): 1198-1217, doi: 10.1080/01402382.2017.1294383. 